\title{
Assessment of the value of a competitive protein binding radioassay of folic acid in the detection of folic acid deficiency
}

\author{
BJ BAIN, SN WICKRAMASINGHE, GN BROOM, RA LITWINCZUK, J SIMS \\ From the Department of Haematology, St Mary's Hospital and Medical School, London W2
}

SUMMARY The diagnostic value of the Becton Dickinson Radioassay Kit $\left({ }^{125} \mathrm{I}\right)$ for the assay of red cell folate has been investigated. The assay was acceptable with regards to precision but was non-linear with changing packed cell volume. Sensitivity of the assay was satisfactory, with 24 of 25 folate deficient patients giving red cell folate values which fell below the reference range. Specificity of the assay in the detection of folate deficiency was less satisfactory. As with microbiological assays, a considerable proportion of vitamin $B_{12}$ deficient patients had low red cell folate values. In addition, low concentrations were found in $12 \%$ of patients who were unlikely to be deficient in either vitamin $\mathrm{B}_{12}$ or folic acid.

During the development of folic acid (folate) deficiency a fall in the serum folate concentration precedes a fall in red cell folate concentration.' As the serum folate falls rapidly after cessation of folate intake,' however, a reduced serum folate is quite common in hospital patients ${ }^{2}$ who do not have a substantial reduction of folate stores. For this reason a red cell folate assay is often preferred for the detection of tissue depletion of folate. ${ }^{23}$ Both serum and red cell folate are almost entirely in the 5-methyltetrahydrofolate form, but serum folate is present as the monoglutamate (folic acid) while red cell folate is present as polyglutamates which must be converted to the monoglutamate before assay. ${ }^{3}$ Serum, red cell, and whole blood folate may be measured by microbiological assay; Lactobacillus casei is the organism most often used. ${ }^{34}$ Microbiological assays are labour intensive, however, and are prone to periodic failure. This has led to attempts to develop radioisotopic competitive protein binding assays. ${ }^{5-7}$

In a detailed assessment of a widely used commercially available kit for the assay of red cell folate by competitive protein binding we have found the performance to be acceptable with regard to precision and specificity and good with regard to sensitivity. But the assay was non-linear with changing packed cell volume.

Accepted for publication 8 May 1984

\section{Material and methods}

A competitive protein binding radioassay of red cell folate (folic acid) was carried out using the Becton Dickinson Radioassay Kit ( $\left.{ }^{125} I\right)$ which uses a protein binder derived from milk and iodine ${ }^{125}$-labelled pteroylglutamic acid (folic acid). The assay was performed as specified by the manufacturer. It requires (a) acidification of the sample by dilution in freshly made ascorbic acid, $2 \mathrm{~g} / 1(0.2 \%)$, and incubation at room temperature for $90 \mathrm{~min}$ to allow endogenous folate conjugase to convert folate polyglutamates to monoglutamates; and $(b)$ heating of the sample to destroy endogenous serum binders of folic acid. Haemolysates were prepared within $48 \mathrm{~h}$ of venesection (usually within $12 \mathrm{~h}$ ) and stored at $-20^{\circ} \mathrm{C}$ for up to 1 week before assay. We did not assay serum folate concentrations in patients' sera and did not correct the "red cell folate" for the relatively small amount of folate in serum.

Within batch and between batch precision were assessed by assaying 20 patient samples twice in one batch and once in another batch and calculating the coefficient of variation of paired samples. Long term between batch precision was also studied as follows. Three haemolysate pools were prepared to have low, normal, and high folate concentrations. Each was divided into $0.4 \mathrm{ml}$ aliquots, which were stored at $-20^{\circ} \mathrm{C}$. One aliquot from each pool was thawed and included in every assay performed over a 5 
month period (32 assays). Mean values and coefficients of variation were calculated.

Recovery of added folate in the radioassay was assessed after adding $100 \mu \mathrm{l}$ isotonic saline containing $1 \mu \mathrm{g}$ crystalline folic acid (BDH Pharmaceuticals Ltd, Alton, Hants) to duplicate $4 \mathrm{ml}$ samples of anticoagulated fresh whole blood from a normal volunteer. Recovery was estimated as a percentage and results on duplicates were averaged. This experiment was carried out on three different samples.

Linearity of the radioassay in the measurement of whole blood folate and red cell folate was studied by making artificial mixtures of red cells and autologous plasma to give packed cell volumes ranging from 0.05 to $0 \cdot 65$. Total folate was assayed on each red cell suspension and red cell folate was calculated both with and without a correction being made for the folic acid in the plasma. Results were expressed as $\mu \mathrm{g} / \mathrm{l}$ of cell suspension and $\mu \mathrm{g} / \mathrm{l}$ of red cells, respectively, and were plotted against packed cell volume. The experiment was carried out on three different samples as detailed, and the red cells from one sample were also suspended to different packed cell volumes in varying mixtures of autologous plasma and isotonic saline such that the concentration of plasma in the red cell suspensions was kept constant. Linearity of red cell and total folate assays was also studied by diluting a haemolysate in folate free medium ( $2 \mathrm{~g} / \mathrm{l}$ ascorbic acid).

The effect of varying the period of incubation of the haemolysate from the recommended $90 \mathrm{~min}$ was studied by freezing the freshly prepared acidified lysate at times varying from zero to $5 \mathrm{~h}$; the lysates so prepared were thawed immediately before assay.

A reference range was derived from samples collected from 200 normal individuals, 100 men and 100 women, aged between 18 and 65 . These were healthy subjects who were having screening blood tests before going overseas or at the time of taking up employment or healthy laboratory staff or other healthy volunteers. Serum folate was also measured in 22 healthy volunteers in order to estimate the degree of inaccuracy introduced by not correcting the assay result for folate present in serum. The reference range was determined over the period in which the diagnostic value of the assay was assessed. Mean values in men and women were compared by Student's t test after logarithmic transformation of the data.

In addition to the samples from normal volunteers, all samples sent to the laboratory for red cell folate assay for diagnostic purposes were assayed over a $2 \frac{1}{2}$ year period starting from January 1981 . In most cases a serum vitamin $B_{12}$ estimation on a sample obtained simultaneously was also performed (Becton Dickinson $\mathrm{B}_{12}{ }^{57} \mathrm{Co}$ Radioassay Kit). ${ }^{8}$ Dur- ing the study all patients suspected on haematological or clinical grounds of having a deficiency of $B_{12}$ or folic acid were investigated as fully as possible, irrespective of the results of folic acid assays. A bone marrow aspirate was performed in patients suspected of having a megaloblastic anaemia, or a neurological syndrome suggestive of $B_{12}$ deficiency, and in most of these patients a deoxyuridine suppression test was also performed. ${ }^{9}$ A Schilling test was advised in all patients with megaloblastic bone marrow; this was performed using a Dicopac Kit (Amersham International), but in most patients parts 1 and 2 of the test were done separately rather than simultaneously. ${ }^{10}$

During the study a deoxyuridine suppression test was also performed on all patients who were having bone marrow aspirates for the investigation of macrocytosis, regardless of the most likely cause of the macrocytosis. The dietary intake of vitamin $B_{12}$, folic acid, ascorbic acid, and iron was assessed by a dietician in patients with megaloblastic anaemia in whom the cause was not readily apparent or in whom the clinical staff suspected a dietary deficiency. Small bowel biopsies and other investigations for malabsorption were carried out when clinically indicated. After full assessment patients were classified using the criteria shown in the Table, excluding any consideration of red cell folate concentration.

Assays were also carried out on 22 samples from patients taking phenytoin sodium, who were not otherwise investigated. In addition, in order to assess the specificity of the assay samples were collected from 50 haematologically normal inpatients. These patients had mean cell volumes of less than 96 $\mathrm{fl}$ and haemoglobin concentrations greater than 13 $\mathrm{g} / \mathrm{dl}$ (men) or $11.5 \mathrm{~g} / \mathrm{dl}$ (women). They were selected to include equal numbers of men and women and equal numbers of medical and surgical patients. Those who had recently been transfused were excluded; in other respects they were unselected.

\section{Results}

\section{PRECISION}

Coefficients of variation of the red cell folate assay on paired samples were $12 \%$ within batch and $26 \%$ between batch (two assays). For haemolysate pools assayed over 5 months in 32 assays between batch coefficients of variation were $12 \cdot 5,10$, and $8.9 \%$ on pools with mean red cell folate values of 73,245 , and $1054 \mu \mathrm{g} / \mathrm{l}$, respectively. Mean values were stable over this period.

\section{RECOVERY}

Recovery of added folic acid in the three studies was $82 \cdot 5,108 \cdot 5$, and $161 \%$ (mean $117 \%$ ). 
Criteria for classification of patients as definitely or probably $B_{12}$ deficient, definitely or probably folate deficient, or not deficient in $B_{12}$ or folate

\begin{tabular}{|c|c|c|c|}
\hline Classification & Criteria & No of patients & $\begin{array}{l}\text { No in whom a } \\
\text { deoxyuridine } \\
\text { suppression test was } \\
\text { done }\end{array}$ \\
\hline $\begin{array}{l}\text { Definite } B_{12} \text { deficiency (with no reason to } \\
\text { suspect folate deficiency) }\end{array}$ & $\begin{array}{l}\text { Megaloblastic bone marrow; abnormal } \\
\text { deoxyuridine suppression test (if done); low } \\
\text { serum } B_{12} \text { value; } B_{12} \text { malabsorption (or known } \\
\text { total gastrectomy) }\end{array}$ & 35 & 28 \\
\hline $\begin{array}{l}\text { Probable } B_{12} \text { deficiency (with no reason to } \\
\text { suspect folate deficiency) }\end{array}$ & As above, but Schilling test not done & 3 & 3 \\
\hline Definite folic acid deficiency & $\begin{array}{l}\text { Megaloblastic bone marrow; abnormal } \\
\text { deoxyuridine suppression test (if done); normal } \\
\text { serum } B_{12} \text {; normal } B_{12} \text { absorption }\end{array}$ & 18 & 14 \\
\hline Probable folic acid deficiency & As above, but Schilling test not done & 7 & 6 \\
\hline $\begin{array}{l}\text { Possible deficiency of both } \mathrm{B}_{12} \text { and } \\
\text { folic acid }\end{array}$ & $\begin{array}{l}\text { Coeliac disease with low serum } B_{12} \text { or } \\
\text { abnormal } B_{12} \text { absorption }\end{array}$ & $\cdot 2$ & 2 \\
\hline $\begin{array}{l}\text { Macrocytic } \pm \text { megaloblastic, but not } B_{12} \text { or } \\
\text { folate deficient }\end{array}$ & $\begin{array}{l}\text { Macrocytic } \pm \text { megaloblastic; deoxyuridine } \\
\text { suppression test normal }\end{array}$ & 45 & 45 \\
\hline
\end{tabular}

\section{LINEARITY}

When red cells were suspended in autologous plasma to give a range of packed cell volumes the total folate (expressed per litre of cell suspension) had a linear relation with the packed cell volume (Fig. 1), but in three studies the intercept of the regression line with the $y$ axis varied between 20.9 and $34.8 \mu \mathrm{g} / \mathrm{l}$ (when the corresponding serum folate values were 2.6 to $3.4 \mu \mathrm{g} / \mathrm{l})$. Similarly, when a haemolysate was serially diluted in a folate free medium, the total folate had a linear relation with packed cell volume but the intercept with the y axis was $25 \mu \mathrm{g} / \mathrm{l}$. The relation between red cell folate (expressed per litre of red cells) and packed cell volume was non-linear whether or not red cell folate was corrected for the serum contribution (Fig. 1).

\section{PERIOD OF INCUBATION OF LYSATE}

Studies of the effect of varying the period of incubation of the lysate showed that the measured red cell folate fell between zero and $90 \mathrm{~min}$ incubation and continued to fall beyond $90 \mathrm{~min}$ (Fig. 2).

\section{VALUES IN NORMAL SUBJECTS}

Red cell folate concentrations in normal subjects had a logarithmic distribution (Fig. 3) and logarithmic conversion was therefore used to derive the geometric mean $(398 \mu \mathrm{g} / \mathrm{l})$ and the $95 \%$ confidence limits (199-795 $\mu \mathrm{g} / \mathrm{l})$. No difference was found between men and women. In the 22 normal subjects in whom both serum and red cell folate were measured the overestimation of red cell folate consequent on not allowing for folate present in serum ranged from 1.2 to $3.9 \%$ (mean $2 \cdot 1 \%$ ).

\section{VALUES IN FOLATE DEFICIENT PATIENTS}

Eighteen patients were classified as definitely folate

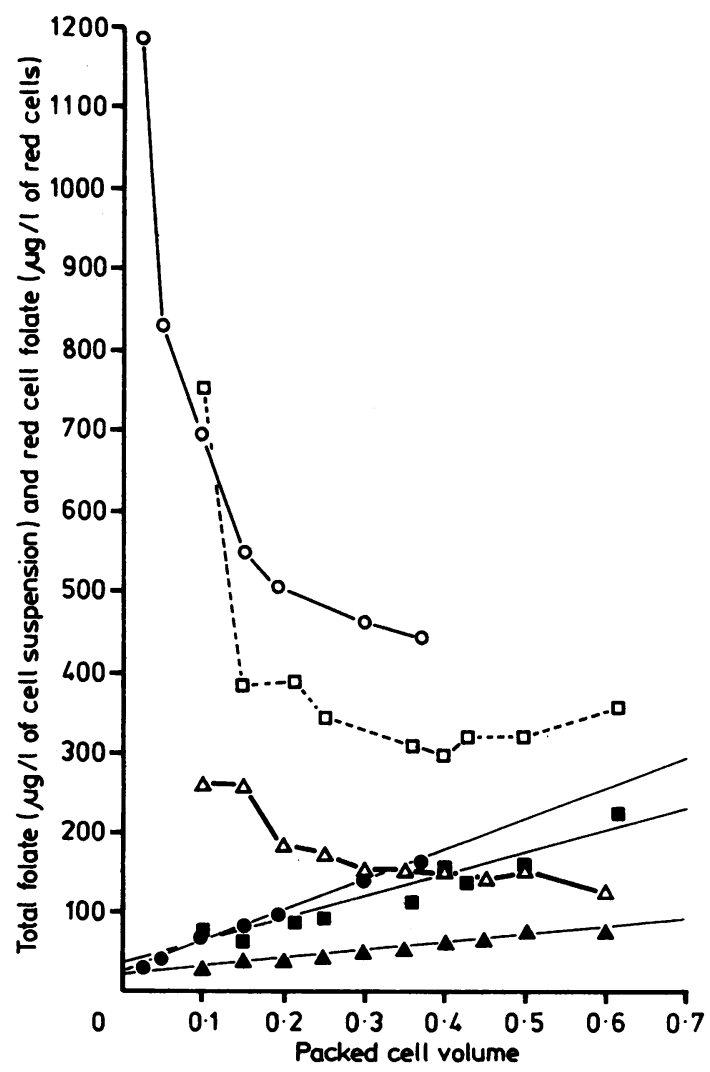

Fig. 1 Total folate $(\square \bigcirc)$ and red cell folate $(\square \circ \triangle)$ in three samples in which packed red cells were mixed with varying volumes of autologous plasma to give a packed cell volume varying between 0.025 and 0.65 . Regression lines of total folate on packed cell volume are also shown. 


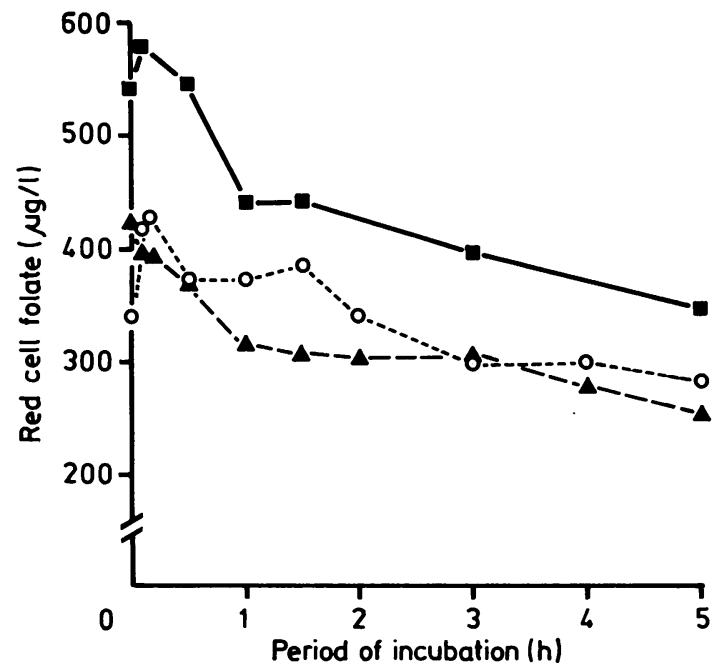

Fig. 2 Serial red cell folate assays on three samples incubated at room temperature for $5 \mathrm{~h}$ (recommended period of incubation $90 \mathrm{~min}$ ).

deficient and a further seven as probably folate deficient (Schilling test not done but serum $B_{12}$ normal plus other criteria shown in Table). As the measured concentrations of red cell folate did not differ between the two groups (Fig. 3) they are considered together; conclusions are not altered if the seven are excluded. The causes of folate deficiency were coeliac disease ( 1 patient); myeloproliferative disorder ( 2 patients); dietary deficiency plus myeloproliferative disorder (1 patient); dietary deficiency plus pregnancy ( 1 patient); dietary deficiency plus malignancy ( 2 patients); and definite or probable dietary deficiency (18 patients). Formal dietary assessments in those considered to have a folate deficient diet gave an estimated intake ranging from 26 to $120 \mu \mathrm{g} /$ day; ascorbic acid intake was also deficient in most patients whose folate intake was deficient. Red cell folate concentrations in the 25 folate deficient patients ranged from 32 to $244 \mu \mathrm{g} / 1$ (Fig. 3), with a median logarithmic value of $116 \mu \mathrm{g} / \mathrm{l}$. Of the 25 deficient patients, 24 fell below the reference range and 13 had values below $100 \mu \mathrm{g} / \mathrm{l}$; however, if we had assessed results using the manufacturer's reference range of 124-600 $\mu \mathrm{g} / \mathrm{l}$ (see discussion) nine of the 25 would have been regarded as normal. The single deficient patient who fell within our normal range had mild folate deficiency superimposed on polycythaemia rubra vera; he was macrocytic with a mild megaloblastosis, numerous giant metamyelocytes, and a deoxyuridine suppressed value of $14 \%$ (normal $<8.6 \%$ ), but his haemo- globin concentration, though lower than his usual value, was within the normal range.

\section{VALUES IN PATIENTS TAKING PHENYTOIN SODIUM}

Of 22 assays requested by clinical staff on patients taking phenytoin, 14 fell below the normal range (Fig. 3) with a median level of $165 \mu \mathrm{g} / \mathrm{l}$.

\section{VALUES IN B $B_{12}$ DEFICIENT PATIENTS}

Thirty five patients were classified as having definite vitamin $B_{12}$ deficiency and a further three as having probable $B_{12}$ deficiency (all three had low serum vitamin $B_{12}$ concentrations but did not have a Schilling test). The underlying cause of vitamin $B_{12}$ deficiency was pernicious anaemia ( 31 patients), extensive ileal resection ( 1 patient), total gastrectomy ( 1 patient), carcinoma of the stomach (1 patient), and malabsorption (undefined pathology) (1 patient). The three patients classified as suffering from probable $B_{12}$ deficiency had red cell folate concentrations similar to those in the patients with definite $B_{12}$ deficiency and are therefore considered with them (Fig. 3 ); conclusions are not altered if they are excluded. The median red cell folate concentration of these 38 patients was $205 \mu \mathrm{g} / \mathrm{l} ; 16(42 \%)$ had red cell folate values falling below our reference range and three had values below $100 \mu \mathrm{g} / \mathrm{l}$. Red cell folate concentrations in $B_{12}$ deficiency were significantly higher than those in folate deficiency $(p<0.001)$.

\section{VALUES IN PATIENTS POSSIBLY DEFICIENT IN VITAMIN B $B_{12}$ AND FOLIC ACID}

In two patients with coeliac disease complicated by vitamin $B_{12}$ malabsorption (shown by the Schilling test) a deficiency of both $B_{12}$ and folate appeared likely. Their red cell folate concentrations were 80 and $145 \mu \mathrm{g} / \mathrm{l}$.

\section{VALUES IN MACROCYTIC PATIENTS NOT}

DEFICIENT IN VITAMIN $B_{12}$ OR FOLIC ACID

Forty five patients investigated for macrocytosis had normal deoxyuridine suppression test values, thus excluding significant vitamin $B_{12}$ or folate deficiency in bone marrow cells. The macrocytosis was attributed to myeloproliferative disorders (including sideroblastic anaemia) (11 patients), excess alcohol consumption or liver disease, or both (13 patients), plasma cell dyscrasia ( 3 patients), and pregnancy ( 1 patient); in 17 cases the macrocytosis was unexplained. Five of the 45 patients were megaloblastic, but in each case this was attributable to a myeloproliferative disorder. Of the 45 patients eight had a red cell folate concentration below the normal range (Fig. 3), with one being below $100 \mu \mathrm{g} / \mathrm{l}$. The mean value of red cell folate in this group was significantly 


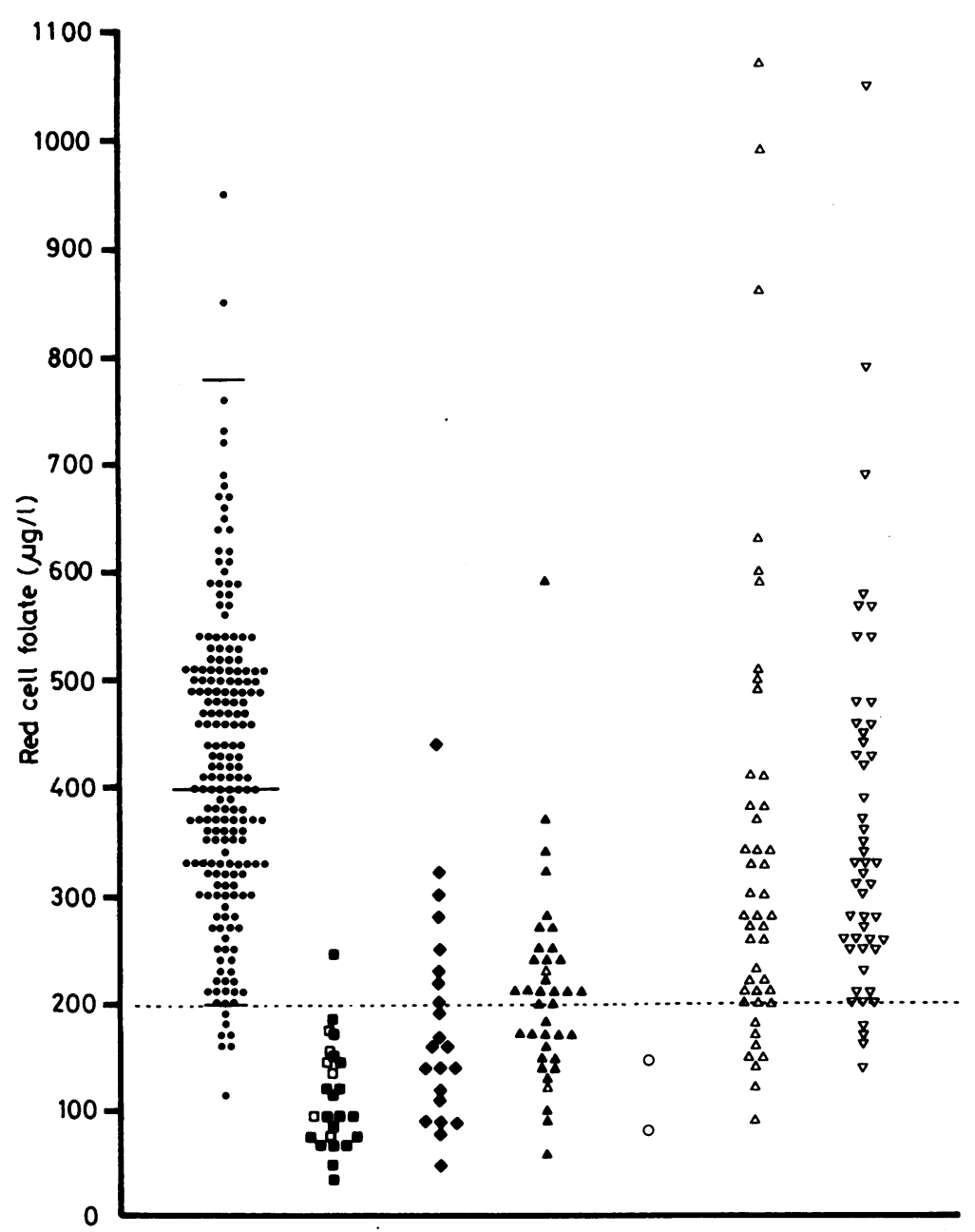

Fig. 3 Red cell folate in 200 normal subjects $\bullet$ and in patients classified as: definitely folate deficient $\square$, probably folate deficient $\square$, taking phenytoin $\diamond$, definitely vitamin $B_{12}$ deficient $\Delta$, probably vitamin $B_{12}$ deficient $\Delta$ (grouped with solid triangles), possibly deficient in vitamin $B_{12}$ and folic acid $\bigcirc$, macrocytic but not deficient in vitamin $B_{12}$ or folic acid $\triangle$ unlikely to be deficient in vitamin $B_{12}$ or folic acid $\nabla$. Solid lines indicate the geometric mean and $95 \%$ confidence limits for normal subjects with the lower limit of normal being represented as a dotted line.

lower than the mean value in normal volunteers. $(p$ $<0.001)$.

\section{VALUES IN PATIENTS NOT SUSPECTED OF FOLATE DEFICIENCY}

Of the 50 patients selected as being unlikely to be folate deficient, four $(8 \%)$ had folate concentrations below the normal range and none had values falling below $100 \mu \mathrm{g} / \mathrm{l}$ (Fig. 3). The mean value was significantly lower than the mean value in normal volunteers $(p<0.01)$.

\section{Discussion}

Since the concentration of folate in red cells is 20 to 50 times that in serum, a measure of whole blood folate, if expressed per unit volume of red cells, approximates closely to a measure of red cell folate, and many laboratories therefore do not correct red cell folate assay results for the folate contributed by serum rather than red cells. In the present study the consequent overestimation of the red cell folate concentration in normal subjects averaged $2 \cdot 1 \%$. 
Since measurement of the serum folate concentration on every sample would double the size and cost of each assay we have chosen to assess the precision, accuracy, sensitivity, and specificity of an uncorrected red cell folate assay.

We have found red cell folate values determined by a competitive protein binding radioassay to have a logarithmic distribution in normal subjects with no difference between men and women and with a reference range similar to ranges for microbiological assays. Our reference range of 199-795 $\mu \mathrm{g} / \mathrm{l}$ differs considerably from that stated by the manufacturer (124-600 $\mu \mathrm{g} / \mathrm{l})$, which also represents $95 \%$ confidence limits and is based on "over 120 healthy volunteers" from three parts of the USA. This difference underlines the importance of each laboratory deriving its own reference range; had we interpreted patient data by comparison with the manufacturer's range quite different conclusions would have been drawn. Precision of the red cell folate assay on paired samples was acceptable, though inferior to the precision claimed for serum folate assay with the same kit (manufacturer's notes), and inferior to precision previously reported for microbiological assays. ${ }^{3}$ Precision of three samples assayed over 5 months was satisfactory. Assayed red cell folate concentrations were stable over this period.

Recovery of added folic acid in the assay was satisfactory, averaging $117 \%$. Linearity of the assay was unsatisfactory. In an ideal assay total folate (expressed per litre of cell suspension) should have a linear relation to the packed cell volume and the regression line should cross the y axis close to zero, at a point corresponding to the concentration of folate in the serum when no red cells are present. If each value is corrected for folate contributed by serum the regression line should pass through zero, as should the regression line for total folate on packed cell volume when a haemolysate is serially diluted in a folate free medium. By contrast, red cell folate should not change with packed cell volume since it is expressed per litre of red cells. We found that although total folate had a linear relation with the packed cell volume, the intercept of the regression line was considerably greater than expected; thus the assay was "measuring" more folate than was present. As a consequence the relation of red cell folate with packed cell volume was curvilinear with an overestimation of folate at all concentrations. The overestimation of red cell folate was particularly pronounced at packed cell volume values likely to be seen in patients with a severe megaloblastic anaemia. The curvilinear relation of red cell folate with packed cell volume was not consequent on a varying amount of folate conjugase or a varying proportion of plasma since the same phenomenon was seen when red cells were suspended in a mixture of saline and plasma to keep the proportion of plasma constant and when a haemolysate was diluted in a folate free medium. The non-linear relation between the measured red cell folate and packed cell volume was not due to an unsuitable $\mathrm{pH}$ for the action of the folate conjugase since the $\mathrm{pH}$ of haemolysates prepared from specimens with the highest and lowest packed cell volumes varied only from $4 \cdot 35$ to 4.01 (data not shown).

Incubation of a haemolysate at room temperature causes a fall in measured red cell folate, which is attributed to polyglutamate having a greater affinity for the binder than monoglutamate. We found that concentrations had not plateaued by 90 min but continued to fall for several hours. The changes in assayed folate concentrations with time are not due to associated changes in $\mathrm{pH}$ since the $\mathrm{pH}$ rises only by about $0.2 \mathrm{pH}$ units between zero time and $3 \mathrm{~h}$. Our data indicate that the recommended period of incubation should be strictly observed in order to obtain consistent results.

Correlations between microbiological and competitive protein binding assay results have been previously demonstrated, ${ }^{7}$ but there has been only limited assessment of the validity of radioisotopic assay of red cell folate in the detection of folic acid deficiency. ${ }^{56}$ We have carried out a detailed assessment of the sensitivity and specificity of a competitive protein binding radioassay in the detection of folic acid deficiency in a considerable number of patients. The presence of folic acid deficiency was determined on criteria independent of folic acid assays, and in most patients a deoxyuridine suppression test was used as an objective biochemical indicator of bone marrow deficiency of vitamin $B_{12}$ or folic acid. Our results show the red cell folate concentration to be a sensitive index of a folate deficiency. Of 25 patients considered to be definitely or probably deficient in folic acid on criteria which were independent of folate values (Table), 24 had low red cell folate concentrations.

Of 22 patients taking phenytoin sodium and 38 patients with definite or probable vitamin $B_{12}$ deficiency, $14(64 \%)$ and $16(42 \%)$, respectively, had low red cell folate concentrations; this is comparable with observations using a microbiological assay that red cell folate is low in 15 to $60 \%$ of patients taking phenytoin sodium ${ }^{11}$ and about $60 \%$ of patients with vitamin $B_{12}$ deficiency. ${ }^{312}$

Since red cell folate as measured by a microbiological assay is often low in vitamin $B_{12}$ deficiency the low concentrations we found in this group of patients are not an indication of non-specificity of the radioassay but rather of non-specificity of any 
red cell folate assay as an indicator of folate deficiency. The frequent occurrence of a low red cell folate level in vitamin $B_{12}$ deficiency makes difficult the diagnosis of a double deficiency state unless serum folate is assayed as well (serum folate being usually normal or high in vitamin $B_{12}$ deficiency). But this difficulty applies to a microbiological as well as to a competitive protein binding assay. A red cell folate concentration of less than $100 \mu \mathrm{g} / \mathrm{l}$ by radioassay usually indicates that a patient is folate deficient. Half of the folate deficient patients but only $8 \%$ of the $B_{12}$ deficient patients had red cell folate concentrations below this value.

A substantial lack of specificity of the red cell folate assay was seen in the data from two groups of patients. Fifty hospital patients selected to make folate deficiency unlikely had mean values significantly below those of normal volunteers and $8 \%$ fell below the reference range. Similarly 45 macrocytic patients with no biochemical evidence of vitamin $B_{12}$ or folate deficiency on a deoxyuridine suppression test had a mean value significantly below that of normal volunteers, and $18 \%$ fell below the reference range. A red cell folate concentration below $100 \mu \mathrm{g} / \mathrm{l}$ was more specific for folate deficiency, being seen in only one of these 95 patients in whom folate deficiency was excluded or unlikely. Since we did not perform simultaneous microbiological assays, we are unable to comment on whether the specificity of the competitive protein binding assay is any worse than that of a microbiological assay.

The overestimation of red cell folate concentration at all packed cell volumes, with the proportionately greater effect at low packed cell volumes, indicates a defect in the competitive protein binding assay for folate. Despite this undesirable feature the assay successfully separates folate deficient subjects, many of whom have low packed cell volumes, from normal subjects. As with microbiological folate assays the radioassay fails to separate effectively folate deficient patients from vitamin $B_{12}$ deficient patients. Specificity of the assay was less satisfactory than sensitivity.
We thank the dieticians of St Mary's Hospital, London W2, and St Mary's Hospital, London W9, Mrs S Barraclough, Miss M Marshall, Miss M Hathaway, and Miss V Williams, for carrying out dietary assessments.

\section{References}

' Herbert V. Experimental nutritional folate deficiency in man. Transactions of the Association of American Physicians 1962;65:307-20.

${ }^{2}$ Chanarin I. The megaloblastic anaemias. 2nd ed. Oxford: Blackwell Publications, 1979:192-5.

${ }^{3}$ Hoffbrand AV, Newcombe BFA, Mollin DL. Method of assay of red cell folate activity and the value of the assay as a test of folate deficiency. J Clin Pathol 1966;19:17-28.

${ }^{4}$ Toennies G, Frank HG, Gallant DL. Blood folic acid activity in normal humans, cancer patients and non-cancer patients. Cancer 1956;9: 1053-8.

${ }^{5}$ Rothenberg SP, da Costa M, Rosenberg Z. A radioassay for serum folate; use of a two-phase sequential-incubation, ligand-binding-system. $N$ Engl J Med 1972;286:1335-9.

- Schreiber C, Waxman S. Measurement of red cell folate levels by ${ }^{3} \mathrm{H}$-pteroylglutamic acid $\left({ }^{3} \mathrm{H}-\mathrm{PteGlu}\right)$ Radioassay. $\mathrm{Br} J$ Haematol 1974;27:551-8.

' Longo DL, Herbert V. Radioassay for serum and red cell folate. J Lab Clin Med 1976;87:138-51.

${ }^{8}$ Bain BJ, Broom GN, Woodside J, Litwinczuk RA, Wickramasinghe $\mathrm{SN}$. Assessment of a radioasotopic assay for vita$\min B_{12}$ using an intrinsic factor preparation with $R$ proteins blocked by vitamin $B_{12}$ analogues. $J$ Clin Pathol 1982;35: 1110-3.

${ }^{9}$ Wickramasinghe SN. The deoxyuridine suppression test. In: Halil C, ed. Methods in haematology: the cobalamins. Edinburgh; Churchill Livingstone, 1983:196-206.

${ }^{10}$ England JM, Snashall EA, de Silva PM. Comparison of the Dicopac with the conventional Schilling test. J Clin Pathol 1981;34:1191-2.

" Chanarin I. The megaloblastic anaemias. 2nd ed. Oxford: Blackwell Publications, 1979:495.

${ }^{12}$ Cooper BA, Lowenstein L. Relative folate deficiency of erythrocytes in pernicious anaemia and its correction with cyanocobalamin. Blood 1964;24:502-21.

Requests for reprints to: Dr BJ Bain, Department of Haematology, St Mary's Hospital Medical School, Praed Street, London W2 1 PG, England. 